quiátrica e psicanalítica) como de crianças que os próprios autores têm em análise, seja no tom informal, na maneira coloquial - preservados tanto na transcrição quanto na tradução - com que os autores interpelam-se e discutem entre si é o que este seminário pode efetivar de mudança na nossa posição a respeito do problema. Uma mudança que nada tem a ver com o encerramento da questão pela afirmação de um tipo ideal (a "psicose infantil") que seria final mente apreendida, mas sim com uma modificação da própria estrutura de nosso discurso. Mudança topológica, que só aparece depois da forçação operada pela formulação da questão nos termos que possibilitam 0 aparecimento deste corte -0 qual tomando no mesmo eixo 0 ainda não [há psicose] e o já aí [desde sempre], ligados por um terá sido, pode eventualmente nos afetar até o ponto do reencontro com o já aí do sujeito como futuro anterior.

Recebido em 22/ 9/2003. Aprovado em 7/10/2003.

Fernanda Costa-M oura fcostamoura@infolink.com.br
“SABE... O CÉU É ENORME, O CÉU NÃO TEM FIM. MAS A TERRA, A TERRA TEM FIM." O sintoma e a clínica psicanalítica. O curável e o que não tem cura. Maria Cristina Ocariz. São Paulo: Via Lettera, 2003, 208 p.

\section{Lia Fernandes}

Psicanalista; mestre em teoria psicanalítica, UFRJ; autora de 0 olhar do engano: autismo e Outro primordial

Este livro trata da fundamental e sempre estruturalmente incompleta tarefa de abordar o resto, o resíduo que se situa no interior da experiência psicanalítica. Toma como tema de seu percurso o sintoma e as transformações que este vai sofrendo no decurso entre as duas pontas de uma análise: 0 início e seu desenlace. Parte de duas constatações fundantes: a do limite do saber na experiência psicanalítica de que decifrar o sentido do sintoma não basta para eliminá-lo - e a de que o sintoma é uma criação defensiva estruturante do sujeito e portanto subsiste, de alguma forma, no fim de uma análise.

Se por muito tempo, entre os lacanianos, didaticamente aprendíamos que a entrada em análise se dá pelo sintoma e sua saída pelo fantasma (através de seu atravessamento), já há algum tempo tem circulado entre nós a proposição de fim da análise como identificação ao sintoma. Isto pode parecer, ao leitor desavisado, no mínimo um disparate. Como deveríamos nos identificar, como produto de um longo e doloroso processo, àquilo que mais nos faz sofrer?

\footnotetext{
${ }^{1}$ Fala de um garoto de 11 anos que, emergindo de uma psicose, encontra este lindo limite.
} 
Aí está a maior originalidade do livro em referência: a distinção entre, por um lado, o sintoma mórbido - aquele que nos petrifica, congela numa repetição empobrecedora e que, nas palavras da autora, nos condena a "sempre fazer a mesma obra, a pintar o mesmo quadro, a repetir os mesmos fracassos" e alcançar as mesmas dolorosas satisfações - e, por outro, o sintoma como invenção, como criação permanente cuja maior obra, como diz Pommier, é o próprio sujeito. É ele o maior produto da criação (artística ou analítica) e deve, a cada instante, re-fundar sua existência, posto que é evanescente.

Inserindo-se este livro numa linhagem freudiana-lacaniana - e o hífen aqui não é por economia, pois a autora tem sempre em mente os dois autores o que perpassa seu denso desenvolvimento teórico, com uma preocupação metapsicológica constante, é seu atravessamento pela clínica, que, como salienta a autora, faz do analista sempre um descobridor aquém de toda síntese acabada, 0 que não deixa de nos lembrar a preciosa advertência metapsicológica de Freud de que "o progresso do conhecimento não comporta nenhuma fascinação das definições" ${ }^{2}$ Devemos acrescentar que 0 próprio "progresso" de uma análise exige do analista que se liberte de igual fascínio, abrindo sua escuta para o sempre novo que advém do discurso do paciente no horizonte de suas mais capturantes repetições.

2 FREUD, S. ( 1915) As pulsões e suas vicissitudes. Edição standard das obras completas de Sigmund Freud, Rio de Janeiro: Imago, 1980, v. XIV. Frase retraduzida por Lacan no Seminário 11, 0s quatro conceitos fundamentais da psicanálise. Rio de Janeiro: Jorge Zahar, 1988.
A clínica privilegiada como referência do livro é a neurose. Apesar de conter uma minuciosa investigação do sintoma ao longo dos diversos momentos da obra freudiana, bem como as inovações lacanianas a propósito do tema, o ponto de vista econômico em Freud e Lacan é o que recebe maior atenção e que trará ao leitor os aportes mais esclarecedores. Se na obra de Freud, a dimensão pulsional relativa ao sintoma começou a figurar como impasse a partir de 1920, em Lacan, o ponto de vista econômico foi ganhando, no decorrer de sua obra, cada vez mais destaque além de uma concepção inicial preponderantemente hermenêutica, centrada no sentido dos sintomas e em seu decorrente processo de decifração. Algo resistia à dissolução do sintoma depois de seu desdobramento significante, um resto, um não-simbolizado que remete ao enigma do sexo e aonde o neurótico insere um saber suturante do qual ele irá, em seguida, padecer. Aqui comparecem os conceitos bem desenvolvidos de gozo e de satisfação pulsional presentes no sintoma.

Mas, felizmente, o livro não padece de nenhuma estratificação que redunda num juízo de valor muito em moda na psicanálise de nossos dias e que privilegia o "último Lacan" ou "a clínica do real" em detrimento de toda construção metapsicológica anterior. Tal redução parece assentar-se no equívoco de que se pudesse pensar num real que não fosse efeito do simbólico e apto a encarnar "a verdade da clínica psicanalítica" a ser enfrentada em percursos analíticos rápidos e ilusórios. Desvio este que já foi feito com Freud há tempos atrás - e que Lacan especialmente denunciou - ao privilegiar-se a segunda tópica psicanalítica em detrimento da primeira.

Distinguindo, dentro das formações do inconsciente, o sintoma do sonho 
enquanto inserido e comprometido, como diz Lacan, num estado econômico mais global do sujeito - à diferença do sonho que é fugaz e instantâneo - a autora, embora não o formule explicitamente, termina por propor o sintoma como decorrente de uma formação de compromisso não mais unicamente entre o desejo e a censura mas entre o desejo e o gozo. Em Lacan, percorre os desenvolvimentos do sintoma como mensagem, como gozo e, por último, como invenção, aproximando-o da idéia de sinthome proposta por este autor em um de seus últimos seminários, sobre Joyce.

Por fim, a proposta, bem lacaniana, que transborda criativamente do livro de Cristina Ocariz é, no tocante ao fim de análise bem como à própria direção da cura, a de fazer algo com o real irredutível - não com aquele que pode ser simbolizado pela análise mas com o real como registro e fundamento do próprio desejo. Este que, como diz Lacan, é como um furão que segue 'impegável', em impasse, nos aguilhoando permanentemente para além e aquém de toda formação significante que lhe deixa sempre escapar como resto. Incurável que - como tão apropriadamente diz a autora - "não se pode curar já que não se cura da vida" nos restando apenas abordá-lo pelas bordas que os significantes que nos constituem nos oferecem - no único grau de liberdade franqueado ao ser falante que é 0 de jogar com suas infinitas combinatórias.

Longe de este fim de análise representar um repouso ou uma aquisição fálica, nos impõe um trabalho inventivo interminável não só com nossas exigências pulsionais mas com a falibilidade e imprevisibilidade da vida. Mas, se do confronto com o impossível do gozo do Outro que se faz numa análise, algo deriva - seria este o nosso consolo? - é de que possamos, neste " amor urgente à criação" seguir experimentando os sempre surpreendentes movimentos do desejo. Para que, com al guma serenidade, possamos, como tão singelamente diz a canção de Chico Buarque, ir "virando peixes, virando conchas, virando seixos, virando areia, na lua cheia" mas - sempre e inevitavelmente - "à béra-mar".

Recebido em 17/9/2003.

Aprovado em 8/ 10/ 2003.

Lia Fernandes

liafernandes@uol.com.br 